Eskişehir Osmangazi Üniversitesi

Sosyal Bilimler Dergisi

Nisan 2019, 20 (Özel Sayı), sayfa aralığı

DOI: 10.17494/ogusbd.

\title{
Fen Bilimleri Öğretmen Adaylarının Eğitimde Çizgi Filmin Kullanımına İlişkin Görüşleri
}

\author{
Asiye BERBER, Burcu ANILAN, İzel Nur ODABAŞ, Dilan ALKAN*
}

\begin{abstract}
Fen Bilimleri Öğretmen Adaylarının Eğitimde Çizgi Filmin Kullanımına Ilişkin Görüşleri

Özet

Öğrencilerin çizgi film seçiminde doğru seçimler yapabilmeleri için öğretmenler yol gösterici olmalıdır. Araştırmamızda, fen bilimleri öğretmen adaylarının eğitimde çizgi filmlerin kullanılmasına ilişkin görüşleri belirlenmeye çalışılmıştır. Bu araştırmada nitel araştırma yaklaşımlarından fenomenolojiden (olgubilim) yararlanılmıştır. Araştırmanın verileri, görüşme türlerinden yarı yapılandırımış görüşme ile toplanmıştır. Verilerin analizinde betimsel analiz tekniği kullanılmıştır. Öğretmen adayları, çizgi filmlerin seçiminde eğlenceli ve dikkat çekici olmasına, izlenilen çizgi filmlerin alt yaş gruplarında çocuğun dünyası ile onun yaşam şeklinin biçimlendirileceği dikkate alınarak uygun konu, karakter ve davranışları sergilemesi gerektiğine vurgu yapmışlardır.
\end{abstract}

Anahtar Kelimeler: Fen Eğitimi, Çizgi Film, Öğretmen Adayı
The Preservice Science Teachers' Views of on the Use of The Cartoon in Education

Abstract

It is important for the parents and teachers to know these positive and negative effects. Teachers must be instructive to the students for making accurate choices in cartoon selection. In our research, opinions on the use of cartoons of science preservice teacher has been determined. Phenomenology among the qualitative research approaches is used in this research. The data of the research is collected with semi-structured interviews. In the analysis of the data, a descriptive analysis technique is used. Preservice teacher emphasize that in the selection of cartoons, the cartoons must present appropriate subject, character and behaviors by considering that the cartoons shall form the life style of the child and the child's world in lower age groups.

Key Words: Science Education, Cartoon, Teacher Candidate

\section{Giriş}

İnsanoğlu günümüzde değişen dünyaya ve gelişen teknolojiye ayak uydurmaya çalışırken birçok teknolojik araç-gereç ve ürünle karşı karşıya kalmaktadır. Insanın hangi yaşta olursa olsun ilgi çekici bu dünyadan uzak durması mümkün görünmemektedir. Telefon,

\footnotetext{
*Asiye BERBER, Dr.Öğr. Üys., Eskişehir Osmangazi Üniversitesi, Eğitim Fakültesi, Matematik ve Fen Bilimleri Eğitimi Bölümü, Fen Bilgisi Eğitimi A.B.D, aberber@ogu.edu.tr,https://orcid.org/0000-0002-8340-4793,Burcu ANILAN, Dr.Öğr. Üys., Eskişehir Osmangazi Üniversitesi, Eğitim Fakültesi, Matematik ve Fen Bilimleri Eğitimi Bölümü, Fen Bilgisi Eğitimi A.B.D, anilan.burcu@gmail.com, https://orcid.org/0000-0002-4153-1866, i̇zel Nur ODABAŞ, Lisans öğrencisi, Eğitim Fakültesi, Matematik ve Fen Bilimleri Eğitimi Bölümü, Fen Bilgisi Eğitimi A.B.D, izelodbss06@gmail.com, https://orcid.org/0000-0001-8359-290X_Dilan ALKAN, Lisans öğrencisi, Eğitim Fakültesi, Matematik ve Fen Bilimleri Eğitimi Bölümü, Fen Bilgisi Eğitimi A.B.D, dlnalkan97@gmail.com, https://orcid.org/0000-0001-7195-7430
} 
tablet, bilgisayar, televizyon gibi pek çok araç günlük yaşamda sıklıkla kullanılan teknolojik araçlar arasında yerini almıştır. Ancak teknolojik araçların doğru ve kontrollü kullanımı son derece önemlidir. Amacı dışında ve gereğinden fazla kullanılan teknolojinin bireylere yarardan çok zarar verdiği bir gerçektir. Her yaştan birey ve özelliklede çocuklar uzun saatler boyu televizyon karşısında vakit geçirmektedirler. Televizyonda izlenilen bazı programların çocuğun gelişimi ve büyümesini etkilediği bilinmektedir. (Rai, Waskel, Sakalle, Dixit, and Mahore, 2017, s. 1375). Yapılan araştırmalarda televizyonun çocukların medya tercihlerinde ilk sırada olduğu ve günde ortalama 3-4 saat televizyon izledikleri, yılda yaklaşık 900 saat okulda, 1500 saat ise evde televizyon izledikleri görülmektedir (Öktem, Sayıl ve Çelenk Özen, 2006; akt. Samur, Demirhan, Soydan ve Önkol, 2014, s. 152).

Çocukların televizyon karşısında geçirdikleri bu sürede genellikle çizgi film izledikleri düşünülmektedir. Çizgi filmler, izleyicinin görsel ve işitsel algısına hitap ettiği için süreç eğlenceli hale dönüşmektedir (Uçan, 2018, s. 1143). Çocuklara "TV'de en çok neyi seyretmekten hoşlanıyorsun?" ve "hangi programları izliyorsun?" şeklindeki birbirine çok yakın iki soru sorulduğunda çocukların doğrudan "çizgi film" yanıtını verdikleri görülmektedir (Cesur ve Paker, 2007, s. 120). Çizgi filmlerin çocuğun davranışlarına, bilişsel ve duyuşsal düzeylerine uygun olması ve çizgi film kahramanıyla kendilerini özdeşleştirmeleri nedeniyle çocuklar çizgi filmleri izlemeyi tercih etmektedir. Çocukların hem gerçek hayatta hem de çizgi filmlerde kendileriyle ortak özelliklere sahip karakterleri model olarak belirledikleri ve benimsedikleri görülmektedir (Oruç, Tecim, Özyürek, 2011, s. 294). Televizyonda izlenen çizgi filmlerin nitelikleri, içerikleri ve algılanması yaş gruplarına göre farklılıklar göstermektedir. Örneğin okul öncesi dönemdeki çocuk, yalın anlatımlı kısa sarımlı (metrajlı) çizgi filmlere ilgi gösterirken, ilkokulda konulu ve uzun sarımlı çizgi filmler dikkat çekmektedir (Güler, 1989, s. 168). Çizgi, filmlerin öğretici, bilgilendirici, kişiliği geliştirici özellikleri olduğu dikkate alınmalıdır. Çizgi filmler çocukların düşünmesine, öğrenmesine, hayal güçlerinin gelişmesine ve kendilerini tanıyabilmelerine olumlu katkılar sağlayabilir. Yalnız çocukların kurmaca ve gerçek arasındaki farkı çoğu kez yetişkinler kadar kolay bir biçimde algılayamadıkları ve televizyon karşısında yetişkinlere oranla daha korumasız oldukları için olumsuz etkilenebilecekleri de göz önünde bulundurulmalıdır.

Çizgi film ile ilgili yapılan çalışmalar incelendiğinde çizgi filmlerde sıklıkla, kurallara uymama, şiddet, cinsiyet ayrımı gibi konuların yer aldığı ve iyi-kötü, kuvvetli-zayıf gibi özelliklere yoğun biçimde vurgu yapıldığı görülmektedir (Kolojarceva, and Artemyeva, 2017, p.1272; Temizyürek ve Acar, 2014, s.34; Özen ve Kartelli, 2017, s.81; Muslu, 2015, s.61; Kara, 2016, s.20; Yıldız, 2016, s.698, Pazarbaşı, 2018, s.28; Özdemir ve Ramazan, 2012, s.160; Rai, Waskel, Sakalle, Dixit, and Mahore, 2017, p.1376). 
Medyanın çocuklar üzerinde şiddet, agresif davranışlar, cinsellik ve zararlı alışkanlıklar edinme gibi konularda olumsuz etkileri bulunmakla birlikte eğitsel açıdan olumlu (Susam Sokağı örneği) etkilerinin de olduğu yapılan çalışmalarla gösterilmiştir (Bar-on, 2000; Canadian Paediatrıc Society Statement, 1999; Lemish, 2013; akt. Koyuncu Şahin, Esen Çoban ve Güney Karaman, 2018, s.128).

Çizgi filmler çocukların iç dünyalarına giden bir yolculuktur. Bu nedenle çocukların seyredecekleri çizgi filmlerin seçimi ve ne amaçla seyredileceği önemlidir. Eğitici televizyon programlarının çocukların hayal dünyası ve el becerilerinin gelişmesine katkı sağladığı bilinmektedir (Kara, 2016, s.21). Öte yandan doğrudan eğitim amaçlı kullanılan ve internet ortamında rahatlıkla ulaşılabilen "Diş Perisi", "Temizlik" isimli çizgi filmler örnek olarak verilebilir (Grafi2000, 2018a; Grafi2000, 2018b). Çoğunlukla çocukları hedef alan programlarda "eğlendirirken, eğitir" ilkesi benimsenmiştir (Özsevgeç ve Saka, 2018, s.726). Öğrenmenin anlamlı ve kalıcı olması için çocuğu düşünmeye, sorgulamaya, araştırmaya, bilgiyi kullanmaya, kendi bilgisini oluşturmaya, hayal kurmaya ve yaratıcı olmaya yönlendiren materyallerle zenginleştirilmiş öğrenme ortamları gerekli görülmektedir (Oruç ve Teymuroğlu, 2016, s.93). Özsevgeç ve Saka, (2018) çalışmalarında öğrencilerin en çok sevdikleri 3 çizgi film arasında Keloğlan Pepee, Fineas ve Firb, Teen Titans Go, RGG Ayas, Gumball, Powerpuff Girls Ben 10 ve Niloya olduğunu belirtilmiştir (s.729). Fineas ve Förb'ün her bölümünde bilime dair kesitler bulunmaktadır. Fineas ve Förb'ün projelerini yaparken bilimsel bilgilerden yararlanıp ileri teknolojik ürünleri kullanarak, farklı düşünme tarzları ile hayalleri, icatları ve akıl gücüyle sürekli bir şeyler üretmeleri çizgi filmin fen bilimleri ile bağlantısını sağlamaktadır (Aydın, 2018, s.53). Çizgi filmlerde bilime, araştırmaya yer verilmesi çocukların hayal dünyasını genişletip fen bilimlerine meraklarını ve ilgilerini artıracaktır. Bu bağlamda, bilimsel kavramların ve anlayışların erken yaşlarda şekillenmeye başlayabilmesi için çizgi filmlerde uygun olan sahnelerde, konu ile ilgili bilimsel içeriğin yer alması önemlidir (Bayır ve Günşen, 2017, s.748).

Okul öncesi dönemde çocukların aile bireylerini örnek aldıkları ve zamanlarının tümünü aileleri ile geçirdikleri, okul dönemi ile birlikte yaşantılarının büyük bir kısmını okulda öğretmenleriyle geçirdikleri bilinmektedir. Bu nedenle özellikle öğretmenler zamana ve teknolojiye ayak uydurarak çocukların ilgisini çekecek ders içi ve dışı materyaller ile derslerine olan ilgiyi artırarak derslerini daha zevkli ve öğretici hale getirebilirler. Çünkü öğrenme öğretme ortamları ve dersler çocukların öğrenirken eğlenebilecekleri çizgi filmler ile desteklenebilir.

Öğrenciler anne babaları ile öğretmenlerini model olarak görmekte ve onların fikir ve düşüncelerini önemsemektedir. Bu yönüyle öğrencilerin okul içinde olduğu kadar okul dışında da eğitici çizgi filmler izlemeleri için yönlendirilmeleri ve doğru seçimler yapabilmeleri için öğretmenlerin bilinçli ve yol gösterici olmaları son derece önemlidir. Çizgi filmler çocukların günlük yaşamlarında ve öğrenmelerinde bu kadar önemli bir yer edinmiş- 
Asiye BERBER | Burcu ANILAN | İzel Nur ODABAŞ | Dilan ALKAN

ken çizgi filmlerin eğitim öğretimde kullanımı ile ilgili alan yazında çok fazla çalışma olmadığı görülmektedir. Bu bağlamda, öğretmenler kadar mesleğe hazırlanan öğretmen adaylarının da çizgi filmlerin eğitimdeki yerini nasıl gördükleri ve bir çizgi filmi öğretmen gözüyle değerlendirmelerinin önemli olduğu düşünülmektedir. Bu çalışmada fen bilimleri öğretmen adaylarının içinde fen bilimleri ve konularını içeren, öğrencilerin hayal dünyasını ve yaratıcılığını geliştirmede yararlı olacağı düşünülen "Fineas ve Förb" isimli çizgi filmi öğretmen gözüyle değerlendirmeleri amaçlanmıştır.

\section{Yöntem}

Fen Bilimleri öğretmen adaylarının eğitimde çizgi filmlerin kullanılmasına ilişkin görüşlerinin ve izlenilen örnek bir çizgi film ile ilgili değerlendirme ve görüşlerinin belirlenmeye çalışıldığı bu araştırma nitel araştırma yöntemlerinden biri olan fenomenoloji biçiminde desenlemiştir. Fenomenoloji sosyal gerçekliği anlamak için bu gerçekliğin meydana getirdiği insan deneyimlerine odaklanır. Fenomenolojik bir çalışmada, insanların tecrübeleri ile bir şeyi nasıl betimledikleri ve tecrübe ettikleri temel alınır (Merriam, 2013; Patton, 2014). Bu kapsamda fenomolojide olguya ilişkin deneyimler sorgulanmakta (Ersoy, 2016), burada insanların ilgili olguları nasıl deneyimledikleri metodolojik, özenli ve derinlemesine betimlenmekte ve deneyimlerinden yola çıkarak geliştirdikleri algı ve anlamlar anlaşılmaya çalışılmaktadır (Patton, 2014). Bu araştırma da fen bilimleri öğretmen adaylarının fen bilimleri öğretiminde çizgi film kullanımı ile ilgili görüşleri ve çizgi filmi bir öğretmen olarak nasıl değerlendikleri, yorumladıkları ve betimledikleri belirlenmeye çalışılmıştır.

\section{1 Çalışma grubu}

Araştırmanın çalışma grubunu 2017-2018 öğretim yılında Orta Anadolu Bölgesinde yer alan bir üniversitenin eğitim fakültesi fen bilgisi eğitimi programında öğrenim gören ve yine aynı fakültede açılan genel kültür seçmeli dersi alan 16 kadın öğretmen adayı oluşturmaktadır. Araştırmanın katılımcıları amaçlı örneklem yöntemlerinden kolay ulaşılabilir durum örneklemesi yöntemine göre belirlenmiştir. Tüm öğretmen adayları araştırmaya katılım konusunda gönüllü ve istekli olmuşlardır.

\subsection{Verilerin toplanması}

Fenomenoloji araştırmalarında kullanılan başlıca veri toplama aracı görüşmedir (Yıldırım \& Şimşek, 2008). Araştırmada, öncelikle çizgi filmlerin eğitimdeki yeri ile ilgili fen bilimleri öğretmen adaylarının görüşlerinin belirlenebilmesi için yarı yapılandırılmış görüşme formu kullanılmıştır. Yarı yapılandırımış görüşme formları, ilgili alanyazın taranarak üç alan uzmanının görüşü alınarak hazırlanmıştır. Hazırlanan soruların açık ve anlaşılır 
olmasını sağlamak için öncelikle görüşme soruları çalışma grubu dışında fen bilgisi öğretmenliğinde öğrenim gören on kişiye uygulanmış ve uzman görüşlerine de başvurularak forma son hali verilmiştir. Araştırmanın ikinci aşamasında öğretmen adaylarının araştırmacılar tarafından belirlenen bir çizgi filmi izlemeleri ve çizgi filmi öğretmen gözü ile bir eğitim öğretim aracı olarak değerlendirmeleri istenmiştir. Değerlendirilen Fineas ve Förb isimli çizgi film içinde fen bilimleri ve konularını içeren, bilime karşı merak uyandıran, öğrencilerin hayal dünyasını ve yaratıcılığını geliştirmek için fayda sağlayabileceği düşünülen bir çizgi filmdir. Çizgi film, internete bağlı birçok cihaz üzerinden yayın hizmeti sağlayan bir kuruluşun çocuklar için belirledikleri çizgi filmler arasında eğitim ve bilim kategorisi altında yer alan çizgi filmler incelenerek belirlenmiştir. Araştırmacılar çizgi film seçiminde eğitim ve bilimle ilişkili olmasını; içerisinde fen bilimleri konularına yer verilmesini göz önünde bulundurmuşlardır. Çizgi film ile ilgili görüşleri yarı yapılandııııış görüşme formu ile görüşme yapılarak toplanmıştır.

\subsection{Verilerin analizi}

Verilerin analizinde betimsel analiz tekniği kullanılmıştır. Betimsel analiz, çeşitli veri toplama teknikleri ile elde edilmiş verilerin daha önceden belirlenmiş temalara göre özetlenmesi ve yorumlanmasını içeren bir nitel veri analiz türüdür. Görüşme ile elde edilen veriler katıımcıların ifadelerinden doğrudan alıntılar yapılarak verilir. Bu analiz türünde temel amaç elde edilmiş olan bulguların okuyucuya özetlenmiş ve yorumlanmış bir biçimde sunulmasıdır (Yıldııı \& Şimşek, 2008). Araştırma verilerinin toplanması için hazırlanmış yarı yapılandııımış görüşme formundaki ana sorular tema olarak kabul edilmiştir. Katılımcı öğretmen adaylarının her birine birer kod verilerek görüşler analiz edilmeye çalışılmıştır. Araştırmanın geçerlik ve güvenirliğini artırmak için katılımcı teyidi sağlanmış, katılımcı görüşlerinden doğrudan alıntılar yapılmış ve alan uzmanlarının görüşlerinden yararlanılmıştır.

\section{Bulgular}

Bu bölümde, fen bilimleri öğretmen adaylarının eğitimde çizgi filmlerin kullanılmasına ilişkin görüşleri ve örnek çizgi film olmak üzere iki başlık atında incelenmiştir. Bu kapsamda fen bilimleri öğretmen adaylarının izletilen bir çizgi film sonrası eğitimde çizgi filmlerin kullanılmasına ilişkin görüşleri iki; örnek çizgi filmle ilgili olarak ise çizgi filmin değerlendirilmesi, çizgi film ile ilgili görüşler olmak üzere iki alt temada toplanmıştır (Şekil 1). Öğretmen adaylarının ifadelerinden doğrudan alıntılar yapılarak temalar altında verilmiş ve yorumlanmıştır. 


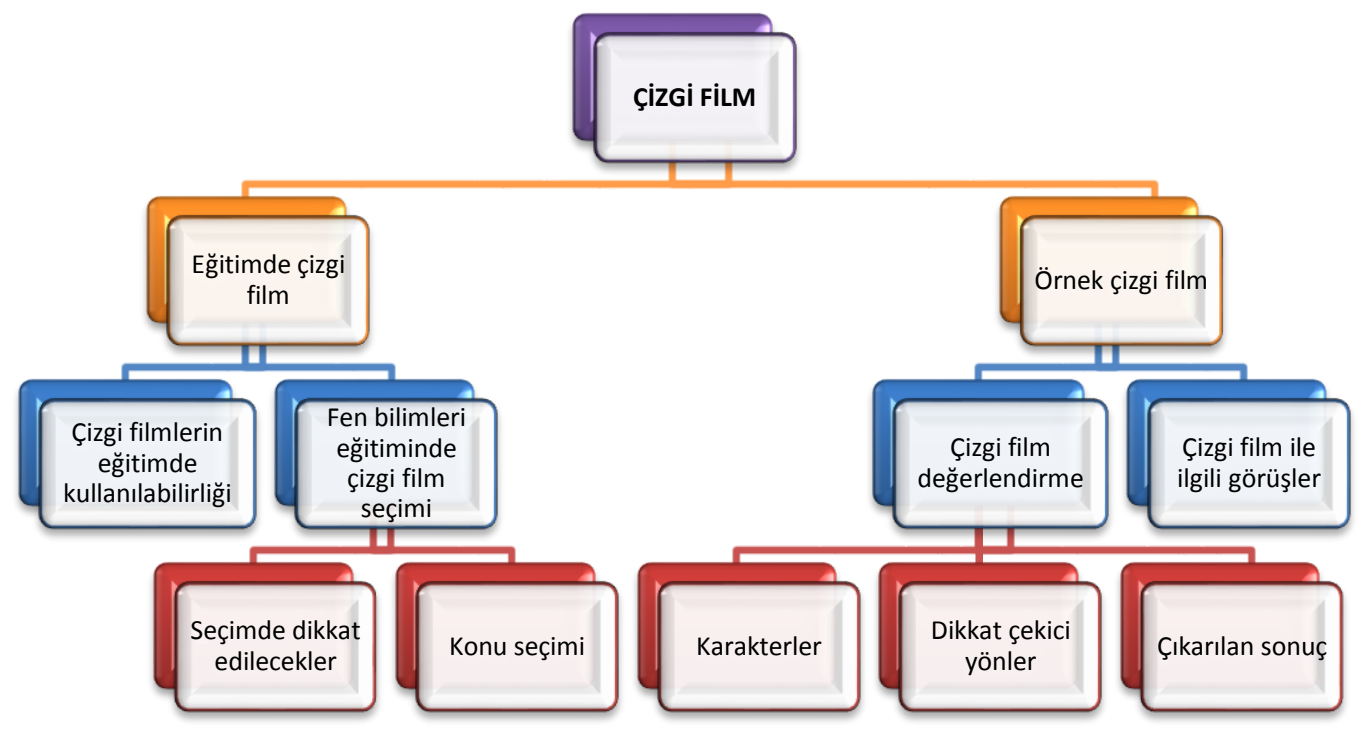

Şekil 1. Fen bilimleri öğretmen adaylarının eğitimde çizgi filmlerin kullanılması ve örnek çizgi filmin değerlendirmesine ilişkin görüşleri

\subsection{Eğitimde Çizgi Film}

Öğretmen adayları ile yapılan görüşmeler sonrası eğitim ve çizgi filmlere ilişkin, çizgi filmlerin eğitimde kullanılabilirliği ve fen bilimleri eğitiminde çizgi film seçimi olmak üzere iki alt tema belirlenmiştir.

\subsection{1. Çizgi filmlerin eğitimde kullanılabilirliği}

Fen Bilimleri öğretmen adaylarının çizgi filmlerin eğitimde kullanılabilirliğine ilişkin ifadelerinden altı farklı tema oluşturulmuştur. Bu temalar "ilgi çekmek, fiziksel-kişisel gelişime faydalı olmak, eğitim öğretimi eğlenceli hale getirmek, hayal gücünü geliştirmek, sınırlılıklar getirilerek kullanmak, kalıc öğrenme ortamı sağlamak" şeklindedir. Aşağıda Tablo 1'de çizgi filmlerin eğitimde kullanılabilirliğine ilişkin temalar ve örnek ifadeler verilmiştir. 
Eskişehir Osmangazi Üniversitesi Sosyal Bilimler Dergisi

Tablo 1. Çizgi filmlerin eğitimde kullanılabilirliği

\begin{tabular}{l}
\hline Çizgi filmlerin \\
eğitimde kulla- \\
nılabilirliği
\end{tabular}

Illgi çekmek “...Çizgi filmler eğitimde çocukların ilgisini çekmek amacıyla kullanılabilir. Çocuklarda merak duygusu uyandırılarak dikkatleri çekilebilir. Bu sayede (Ö1, Ö2, Ö5, Ö6, derse karşı olan tutum ve motivasyonları artırılabilir. Zaman zaman aşırıya Ö10, Ö14) kaçmayacak şekilde çizgi filmler izletilerek merak duygusu uyandırılabilir ve bu sayede konu üzerinde çocuğun dikkati yoğunlaştırılabilir..." Ö1.

“...Yaş grubuna bağlı olarak çizgi filmlerde bulunan görsel ögeler, renkli karakterler vb. öğrencinin dikkatini çekeceğinden güdülenmeyi de arttıracaktır..." Ö5.

“...Çünkü ilgi çekici olduklarından çocukların hayal dünyası ile daha eğitici ve öğretici buluyorum..." Ö6.

Kişisel-fiziksel “...Bazı çizgi filmler çocukların kişisel ve fiziksel gelişimi için yararlıdır. gelişime faydalı Çocuklar çizgi filmlerdeki karakterleri benimseyip onların davranışlarını olması taklit etmeye başlarlar..." Ö2

(Ö2, Ö3, Ö4) “...Çizgi filmin içeriği; çocukların özellikleri göz önünde bulundurularak kişilik gelişimine katkı sağlayacak nitelikte olursa çizgi filmlerin eğitimde kullanılması olumlu sonuçlar verecektir..." Ö3

Eğitim öğretimi “...Çocuklar çizgi filmleri sevdiği ve sıkılmadan izledikleri için onlarda meeğlenceli hale rak uyandırır ve eğlenceli bir öğretim için kullanılabilir...” Ö2.

getirmek

“...Özellikle lise öncesi eğitim grubu için çizgi filmler ile anlatılmak isteni(Ö2, Ö4, Ö7, len birçok matematik, geometri ve fen bilimleri ile ilgili konular daha Ö14) akılda kalıcı ve eğitici aynı zamanda da eğlenceli olduğu düşüncesindeyim. . Genel anlamda bakılacak olursa ise herkes için bu tür etkinliklerle anlatılmak istenilen mesajlar ya da konular daha akılda kalıcı oluyor ve izleyici kitle sıkılmadan hem eğlenip hem de öğrenebiliyor..." Ö7.

Hayal gücünü “...Çizgi filmleri hayal gücünü geliştirici ve eğitici olduğunu düşünüyogeliştirmek rum..." Ö4. 
(Ö4, Ö6, Ö8) “...Eğitsel çizgi filmler çocukların hayal gücü ve yaratıcılıklarını geliştirmesinde, olaylara farklı açılardan bakmalarına ve birçok yeni şeyi keşfetmelerine olanak sağlar..." Ö8

Sınırlııklar geti- "...Kullanılabilir fakat içeriği ve kalitesi bakımından seçici olunmalıdır. rilerek Günümüzdeki bazı çizgi filmlerde çocuklara kötü örnek olabilecek şeylerin olduğunu düşünüyorum. Çocuklarında o yaşlarda gördüğünü yapma gibi (Ö1, Ö2, Ö3, Ö9, bir özelliği olduğundan, kişilik gelişimini olumsuz da etkileyebilir, olumlu Ö11, Ö12) da..." Ö3.

“...Çizgi filmlerin eğitim için kullanılabileceğini düşünüyorum. Ancak dozunda olması gerektiği kanısındayım. Eğitim sadece çizgi filmle olmamalıdır. Çizgi filmle olduğu kısımda da çocuğun çok fazla hayal dünyasına kapılacak düzeye çıkmasını göz önünde bulundurarak ailelerin/eğitimcilerin bu kritere göre seçim yapmasında fayda olduğunu düşünüyorum. Demem şu seçilen çizgi filmlerin belli kriterlerde olması doğrultusunda elbette kullanımı faydalı olacaktır..." Ö12.

Kalıcı öğrenme “...Çocuklara bir bilgi öğretirken düz ve geleneksel bir anlatım yerine çizgi sağlamak ( Ö7, Ö11, Ö13) filmlerle bir konunun desteklenerek anlatılmasını daha akılda kalıcı olduğuna inanıyorum..." Ö11.

“...Görme ve işitme duyularını bir arada kullanmasını sağlayarak hafızalarında bence daha etkili ve kalıcı bir öğrenme meydana getirmektedir..." Ö13.

Öğretmen adaylarının büyük çoğunluğu çizgi filmleri eğitiminde kullanılabilir olarak gördüklerini belirtmişlerdir. Eğitimde verimli bir şekilde kullanılabilmesi için çizgi film seçiminin önemli olduğu ve belirli kriterlere göre seçilmesinin katkı sağlayacağı belirtilmiştir. Çizgi filmlerin görsel ve animasyonlar içermesinin öğrencilerde merak uyandıracağı ve öğrencilerin dikkatini çekerek derse olan motivasyonunu arttıracağını ve eğlenceli bir öğrenme ortamı sağlayacağını ifade etmişlerdir. Çizgi filmler ile öğrencilerin hayal güçleri ve yaratıcılıklarının gelişeceğini bunun akademik başarılarına katkı sağlayacağına kalıcı bir öğrenme olacağına değinmişlerdir.

\subsubsection{Fen bilimleri eğitiminde çizgi film seçimi}

Yapılan görüşmeler sonrası öğretmen adaylarının çizgi filmlerin seçimine yönelik önerileri doğrultusunda çizgi filmlerin seçiminde dikkat edilecek unsurlar ve çizgi filmlerin 
konularının belirlenmesi şeklinde iki alt tema belirlenmiş ve bu iki tema altında öğretmen adaylarının ifadelerinden örnekler sunulmuştur.

\subsubsection{Fen bilimleri eğitiminde çizgi film seçiminde dikkat edilecek unsurlar}

Öğretmen adayları fen bilimleri derslerinde kullanacakları çizgi filmleri seçerken bazı sınırılıkların olması gerektiğini belirtmişlerdir. Öğretmen adayları ile yapılan görüşmelerin analizi sonucu çizgi film seçiminde dikkat edilecek unsurlar Tablo 2' de temalar altında toplanıp örnek ifadelerle verilmiştir.

Tablo 2. Fen bilimleri eğitiminde çizgi film seçiminde dikkat edilecek unsurlar

\begin{tabular}{|c|c|}
\hline $\begin{array}{l}\text { Çizgi film } \\
\text { seçiminde } \\
\text { dikkat edile- } \\
\text { cek unsurlar }\end{array}$ & Örnek ifadeler \\
\hline
\end{tabular}

Doğru bilgi “...Çizgi film seçilirken öncelikle bilgilerin doğruluğuna, yanlış ve eksik bilgi kullanılması kullanılmamasına dikkat ederim. Bilgilerin güncel olması da önemlidir..." Ö1.

(Ö1, Ö2, Ö3, Ö5, Ö11)

“...Ders kazanımlarını kapsamasına, bilgilerin doğru ve güncel olmasına dikkat ederim..." Ö3.

“...̇çerdiği bilgilerin doğruluğundan emin olurum. Ardından öğrencilerin gelişimlerine etki edebilecek zararlı içerik var mı kontrol ederim...” Ö5.

Ders içeriğine “...̈ncelikle ders kazanımlarına uygun ve doğru bilgiler içerip içermediğiuygun olması ne bakarım. Aynı zamanda eğlenceli, merak uyandırıcı olmalı..."Ö2.

(Ö1, Ö2, Ö3, “...Öncelikle şiddet içeren görüntülerin olmamasına, fen konuları ile ilişkili Ö4, Ö5, Ö6, olmasına ve yaş düzeyine uygun olmasına dikkat ederim..." Ö8.

Ö7, Ö8,

Ö9,Ö10 Ö11, “...Öncelikle o sınıf düzeyine uygunluğuna dikkat ederim. Çizgi filmde Ö14) geçen terim anlamlı kelimelerin öğrencilere ağır ve fazla gelmemesine onlar için anlaşılır olmasına dikkat ederim..." Ö14. 


\footnotetext{
Gerçeğe uy- "...Gerçeklik ilkesinden çok uzakta ve gerçeğe aykırı olmamasına, doğru gun olması bilgiler içermesine ve içeriğinde başka sübliminal mesajlar bulunmamasına dikkat ederim..." Ö11.

(Ö4, Ö11,

Ö12, Ö13) “...Çünkü öğrenci görseli ve sesi aynı anda takip ederek olay örgüsünü anlamaya çalışıyor. Sadece duyarak öğrenme yapıp kendi hayal dünyasında somutlaştırmaya çalışmıyor..." Ö13.

İlgi çekici “...Öğrencilerin yaş grubuna hitap etmesine, dikkat çekecek nitelikte ololması masına, ders kazanımlarını kapsamasına, bilgilerin doğru ve güncel olmasına dikkat ederim..." Ö3.

(Ö1, Ö2, Ö3,

Ö8, Ö9, Ö10) “...Özellikle çocukların günlük hayatta ilgilerini çeken konuları içeren ve dersin konusu ile bağlantılı örnek olacak şekilde olan çizgi filmleri tercih ederdim...". Ö9.

Eğlenceli ol- “...Öncelikle çocukların hazırbulunuşluk düzeyine uygun olmasını eğlendiması rirken eğiten düzeyde olması ve Fen'in hayatla ilişkisini bağdaştıran şekilde olmasına dikkat ederdim... "Ö4.

(Ö2, Ö4, Ö5,

Ö9, Ö11 “...çocukların eğlenerek izlemesine dikkat ederim...” Ö11.
}

Öğretmen adayları fen bilimleri derslerinde çizgi filmleri kullanacaklarını fakat her tür çizgi filmin fen bilimleri öğretiminde kullanılmasını doğru bulmadıklarını, seçim yaparken bazı unsurlara dikkat etmeleri gerektiğini belirtmişlerdir. Bu unsurlar, öğretmen adaylarının ifadelerinden yola çıkarak beş farklı tema altında toplanmıştır. Öğretmen adayları seçilecek çizgi filmde öncelikle doğru bilgilerin kullanılması, bilimsel açıdan yanlış bir bilgi içermemesi gerektiğini belirtmişlerdir. Dersin içeriğine uygun bir seçim yapılması görüşündedirler. Kullanılan çizgi filmlerin gerçeğe uygun olması, gerçekten tamamen farklı olup bir hayal ürünü olmamasına özen göstereceklerini belirtmişlerdir. Çizgi filmin eğlenceli ve ilgi çekici özelliğe sahip olması ve bu sayede etkili öğrenmenin gerçekleşebileceğini vurgulamışlardır.

\subsubsection{Fen bilimleri eğitimine yönelik çizgi filmlerde konu seçimi}

Öğretmen adayları fen bilimleri derslerinde eğitim öğretim aracı olarak çizgi filmleri kullanırken bazı konularda çizgi filmlerin kullanımının faydalı olacağını belirtmişlerdir. 
Şekil 1'de öğretmen adayları ile yapılan görüşmeler sonrasında çizgi film seçimi için önerdikleri konu isimlerinden oluşturulan kelime bulutu verilmiştir.

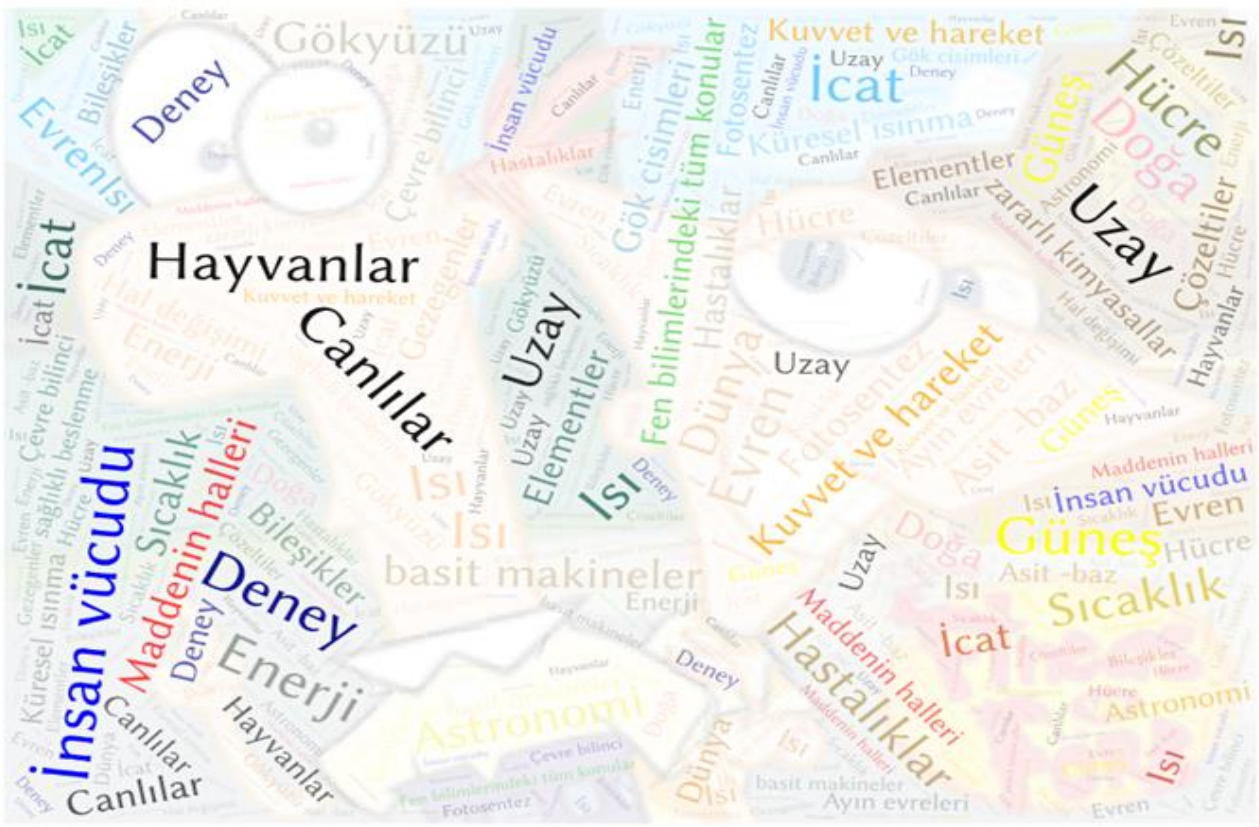

Şekil 2. Fen bilimleri eğitimine yönelik çizgi film konu önerileri

Öğretmen adaylarının önerdikleri çizgi film konu önerileri kelime bulutunda da görüldüğü gibi insan vücudu, kuvvet ve hareket, uzay, canlılar, güneş, doğa, deney ve fen bilimlerinde tüm konular olmak üzere bazı başlıklar ön plana çıkmaktadır. Bunun dışında da kelime bulutunda görülen pek çok fen bilimleri konusuna yönelik çizgi filmlerin kullanılabileceğini belirtmişlerdir. Öğretmen adaylarının örnek ifadeleri aşağıda verilmiştir.

“...Hemen hemen bütün konularda kullanılabileceğini ve faydalı olacağını düşünüyorum..."

"...Özellikle maddenin halleri, kuvvet ve hareket gibi öğrencinin zihninde canlandırmakta zorlandığı konularda kullanılması faydalı olur..." Ö5

"...Soyut kavramların olduğu konularda faydalı olabilir. Örneğin; insan vücudu, ayın evreleri, gökyüzü... gibi konularda..." Ö6 
Asiye BERBER | Burcu ANILAN | İzel Nur ODABAŞ | Dilan ALKAN

“...Doğayı, hayvanları ve uzayı tanımaya ve anlamaya yönelik çizgi filmlerin daha eğlenceli ve dikkat çekici olacağını düşünüyorum..." Ö8

Bir konu ismi vermeyen öğretmen adayları da anlaşılması zor olan ve günlük yaşamla ilişkili konulara ilişkin çizgi filmlerin seçilebileceğini belirtmişlerdir. Aşağıda öğretmen ifadelerinden alıntılara yer verilmiştir. lar..." Ö10.

“...Özellikle çevre bilinci, sağlıklı beslenme, günlük hayatta karşılaştığımız durum-

“...Çocukların daha çok iç içe olduğu ve anlamakta zorluk çekmeyeceği konularda kullanımı faydalı olur..." Ö4.

Öğretmen adayları genel olarak çizgi filmlerin konu seçiminde fen bilimlerinde anlaşılması zor, soyut ve günlük yaşam ile ilişkilendirilebilen konuların seçilebileceğine vurgu yapmışlardır.

\section{2 Örnek Çizgi Film}

Öğretmen adayları ile eğitimde çizgi filmlere ilişkin yapılan görüşmeler sonrası ders yönetim sistemi aracılığıyla örnek bir çizgi film paylaşılmış ve verilen linkten "Fineas ve Förb-Hız Treni” isimli çizgi filmi izlemeleri istenmiştir (Disney Channel Türkiye, 2018). Araştırmada öğretmen adaylarına izletilen 'Fineas ve Förb-Hız Treni' adlı çizgi filmin ekran görüntüleri Şekil 3 de verilmiştir. 

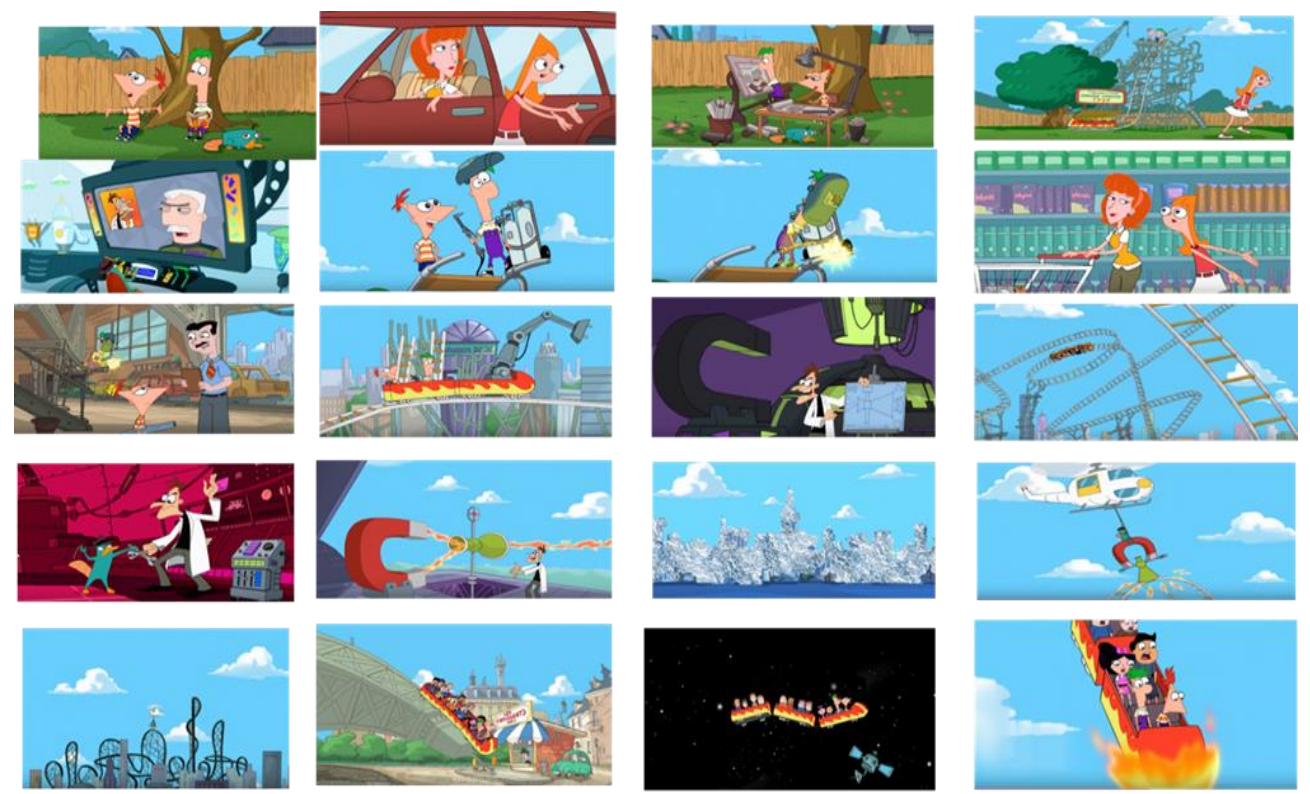

Şekil 3. "Fineas ve Förb-Hız Treni" isimli çizgi filmden görüntüler

Öğretmen adaylarının çizgi filmi izledikten sonraki ifadelerinden "çizgi filmi değerlendirme ve çizgi filme ilişkin görüşler" olmak üzere iki alt tema belirlenmiştir.

\subsection{1. Çizgi filmi değerlendirme}

Öğretmen adaylarının çizgi filmi değerlendirme teması altında çizgi filmi karakterler, çizgi filmin dikkat çeken yönleri ve çizgi filmden çıkarılan sonuç olmak üzere üç alt temada değerlendirdikleri görülmektedir.

\subsubsection{1. Çizgi filmdeki karakterlerin değerlendirilmesi}

Çizgi filmi izleyen öğretmen adaylarının çizgi filmdeki karakterleri özelliklerine göre değerlendirdikleri görülmektedir. Çizgi filmdeki Fineas, Förb, Candice, Perry, anne ve doktor karakterlerinin özelliklerinden bahsetmişlerdir. Her bir karaktere ilişkin öğretmen adaylarının değindikleri karakter ve bunların özellikleri aşağıda Şekil 4' de verilmiştir. 


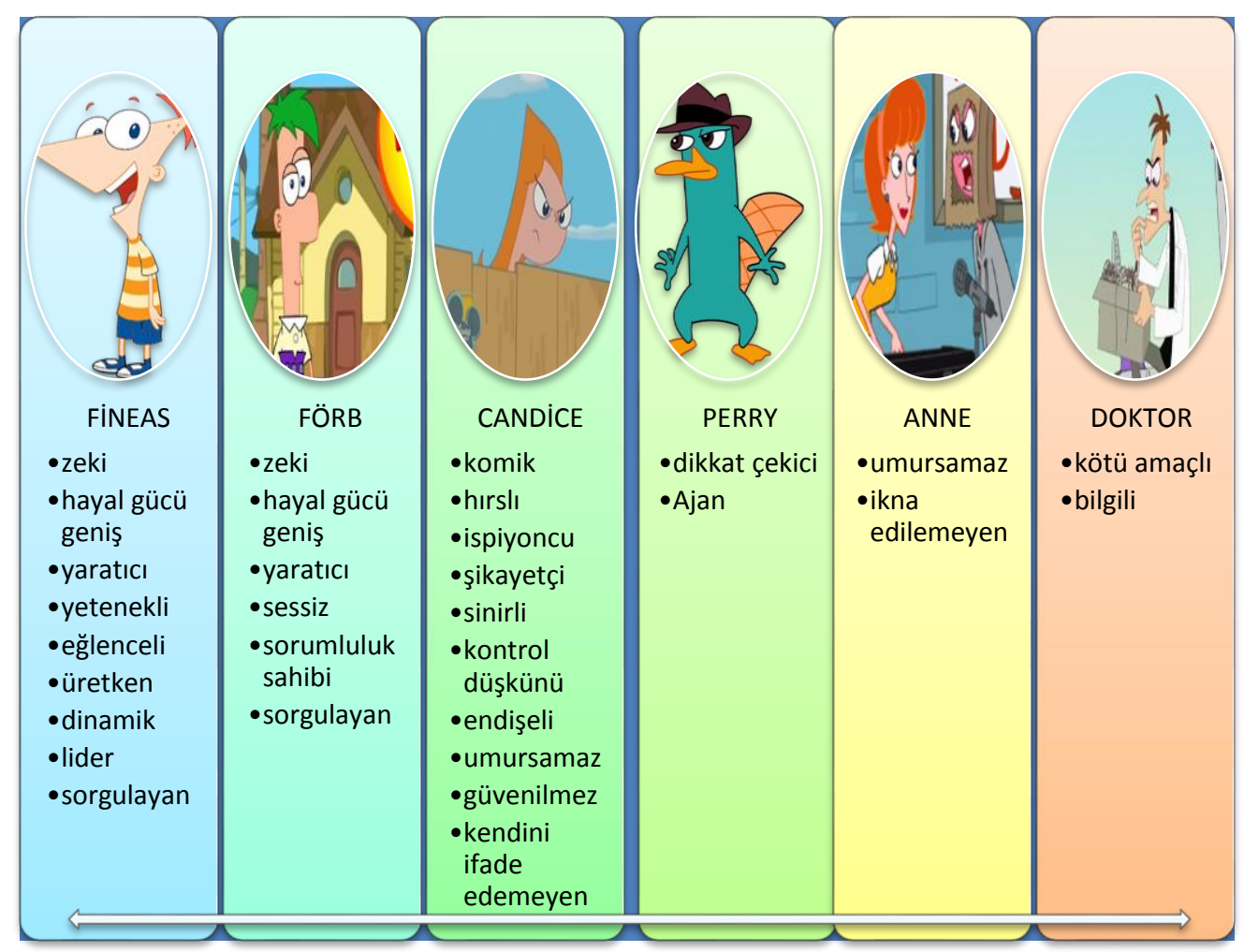

Şekil 4. Çizgi filmdeki karakterler ve özellikleri

Öğretmen adaylarının genel olarak karakterlerin özelliklerine ilişkin ifadelerinden örneklere aşağıda yer verilmiştir.

“...Fineas ve Förb hayal gücü geniş, boş oturmayı sevmeyen zeki çocuklar, Candice çok hırslı. Ispat edemese de her seferinde kardeşlerini ispiyonlamaya devam ediyor. Perry dikkat çekici bir karakter. Sahiplerinin yanında evcil bir hayvan, normalde ise bir ajan..." Ö2. си..." Ö3.

“...Fineas ve Förb eğlenceli, zeki, yaratıcı ve üretkenler. Candice; sinirli, ispiyon-

“...Ana karakterin ablasına oldukça güldüm kendini bir türlü annesine kanıtlayamazken oldukça komik sahneler ortaya çıkartılmış. Ana karakter oldukça zeki ve o küçük 
yaşında birçok mühendisi geçecek yeteneğe sahip. Öyle ki bir fabrika müdürünü dahi etkilemiş durumda. Doktor oldukça fizik bilir biri bilgisi var ancak kötü amaçlar peşinde..." Ö7.

"...Fineas: Aklına koyduğunu yapan ve insanları yönlendiren, Förb:Sessiz bir karakter, ablaları: Konuyu anlamadan annelerine söyleyen, endişeli ,egolu bir karakter, anneleri: Umursamaz ve ablalarına hiçbir şekilde inanmayan..." Ö11.

"...Fineas üretken ve sürekli bişeylere ilgi duyuyor asla kafasına koyduğundan vazgeçmiyor. Förb ise kendi fikir üretmeden sadece kendine denilenleri yerine getiriyor. Ablaları sürekli onların yaptıklarını kanıtlamak ve annesine şikayet etmekle meşgul..." Ö14.

Genel olarak öğretmen adaylarının çoğu Fineans ve Förb'ün zeki, hayal gücü geniş ve yaratıcı özelliklerine vurgu yapmışlardır. Abla karakteri olan Candice'in genel olarak şikâyet etmesi, olayları ispiyonlaması ve bunu ispatlayamadığı görülmektedir. Annenin umursamaması ve ablaya inanmaması, doktorun bilgisini kötüye kullanması, Perry'nin evcil bir hayvan olması katılımcılar açısından dikkat çeken özelliklerden olmuştur.

\subsubsection{2. Çizgi filmin dikkat çekici yönleri}

Öğretmen adaylarının ifadelerinden çizgi filmlerin dikkat çekici yönlerinin karakterler, gerçek dışı olaylar ve bilimsel kavramlar şeklinde üç alt tema altında toplandığı görülmüştür. Tablo 3'te bu alt temalara ve öğretmen adaylarının örnek ifadelerine yer verilmiştir.

Tablo 3. Çizgi Filmin Dikkat Çekici Yönleri

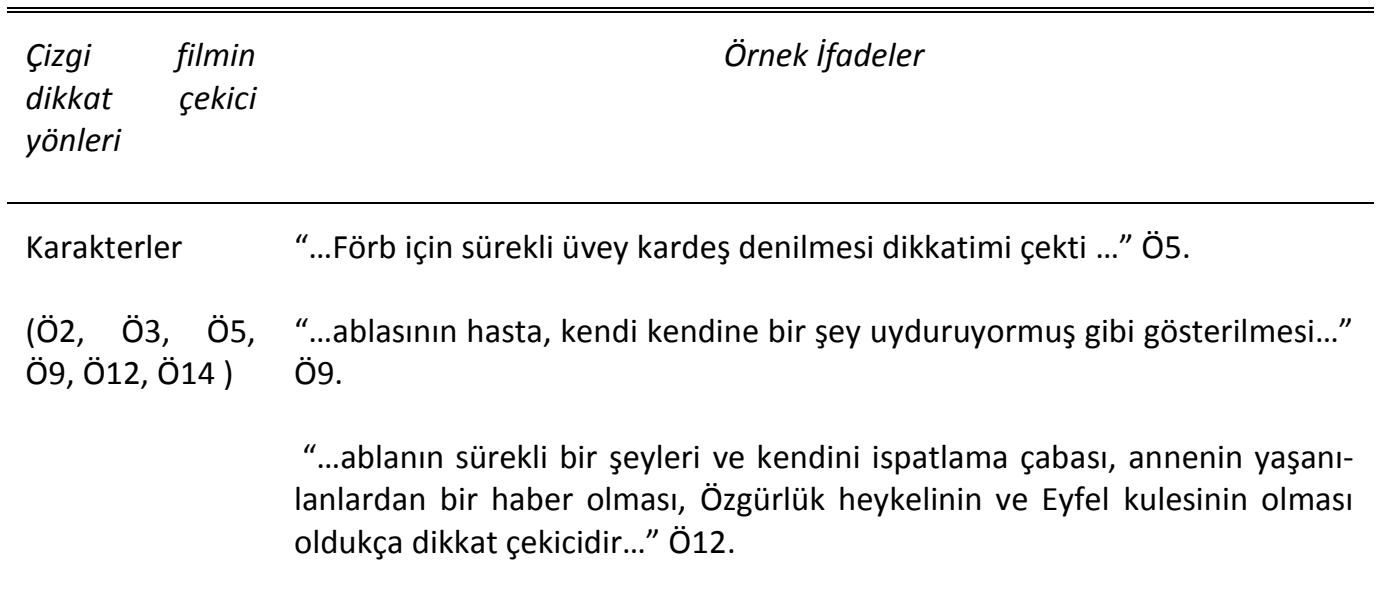


Asiye BERBER | Burcu ANILAN | İzel Nur ODABAŞ | Dilan ALKAN

\footnotetext{
Gerçek dışı “...Çocuğun çok farklı ve gerçekleştirilmesi zor etkinlikleri yapabilmesi..." olaylar Ö4.

(Ö1, Ö4, Ö6, “...Hız treni yapabilmeleri için yeterli bir bilgi düzeyine sahip olmaları Ö8, Ö9, Ö11, gerekirken, yaş aralığı düşünüldüğünde böyle bir şey olamayacağı dikkatimi Ö13) çekti. 9.13 de ablanın şaşırma efekti bir maymunun çıkardığı ses ile aynı verilmesi Darwin e yapılan bir gönderme olacağı dikkatimi çekti..." Ö6.

“...o yaş aralığındaki bir çocuğun yapamayacağı bir şeyi yapıyor gibi göstermesi..." Ö9.

“...Hız treniyle başka ülkelere gidilmesi, dünya dışına çıkılması ve hiçbir şekilde trenden düşmemeleri ve çocukların başına hiçbir şey gelmeden evlerine geri dönebilmesi ayrıca..." Ö11.

Bilimsel kav- "...Doktorun alüminyum tabaka kullanması aynı zamanda ortaya çıkardığı ramlar buluşu ve işlevi ilgimi çekti..." ö7.

(Ö7, Ö11, Ö12, “...hiç bilmediğim bir hayvan olan ornitorenk öğrenmiş olmam ve bu hayÖ13) vanın yapmış oldukları dikkatimi çekti ..." Ö11.

“...Benim en çok Profesörün mıknatıs kullanarak şehrin doğu ve batısını birleştirmek isteyip bunun için batı tarafındaki binaları alüminyum ile kaplaması. Bu sırada yörünge kavramından bahsetmesi. Çocukların dünyadan uzaya çıktıklarında uzayda ki uyduların gösterilmesi ve dünya katmanına girdiklerinde vagonun ön kısmının alev alması. Anne ve abla marketten çıktıkları sırada annenin buzlu gıdalar aldım erimeden eve gitmeliyiz demesi benim dikkatimi çekti..." Ö13.
}

\subsubsection{3. Çizgi filmden çıkarılan sonuçlar}

Öğretmen adaylarının çizgi filmi izledikten sonra çizgi filmden çıkardıkları sonuçları belirten ifadeleri kendini yetiştirme, hedeflere ulaşma, bilgi edinme olmak üzere üç alt tema altında toplandığı görülmektedir. Alt temalar ve örnek ifadeler Tablo 4'te sunulmuştur. 
Eskişehir Osmangazi Üniversitesi Sosyal Bilimler Dergisi

Tablo 4. Çizgi Filmden Çıkarılan Sonuçlar

\begin{tabular}{|c|c|}
\hline $\begin{array}{l}\text { Çizgi filmden } \\
\text { çıkarılan sonuçlar }\end{array}$ & Örnek ifadeler \\
\hline $\begin{array}{l}\text { Kendini yetiştir- } \\
\text { me }\end{array}$ & $\begin{array}{l}\text { “...Dikkatimizi çeken konularda bilgi edinmeli ve gerektiğinde uygula- } \\
\text { maya geçirerek merak ve bilgi düzeyimizi arttırabiliriz” Ö1 }\end{array}$ \\
\hline \multirow[t]{2}{*}{ (Ö1, Ö2, 03) } & “...Boş zamanlarımızı değerlendirmeliyiz...” Ö2. \\
\hline & ...Yaratıcı ve üretken olmalıyız...” Ö3. \\
\hline \multirow{5}{*}{$\begin{array}{l}\text { Hedeflere Ulaş- } \\
\text { ma } \\
\text { (Ö2, Ö5, Ö8, } \\
\text { Ö12, Ö14) }\end{array}$} & “...Hayal ettiğimiz hedeflere istersek ulaşabiliriz...” Ö2. \\
\hline & “...Önemli adımlar atmadan önce yapılabilecek en güze hazırlık hayal \\
\hline & kurmaktır..." Ö5. \\
\hline & $\begin{array}{l}\text { "Çizgi filme iyi yönünden bakarsak, hayatta bir şeyi çok istersek başa- } \\
\text { rabileceğimizi ve çalışarak elde edebileceğimizi anlatıyordu" Ö8. }\end{array}$ \\
\hline & “...Ürettiğin fikirlerin ve yapmak istediklerinden vazgeçmemek...” Ö14. \\
\hline \multirow{3}{*}{$\begin{array}{l}\text { Bilgi edinme } \\
\text { (Ö1, Ö6, Ö7, Ö9, } \\
\text { Ö10, Ö11, Ö13) }\end{array}$} & “... Ornitorenk adında bir hayvan olduğunu öğrendim...” Ö6. \\
\hline & “...Sürat treni ile sürat, hız kavramının öğrenilmesi...” Ö9. \\
\hline & $\begin{array}{l}\text { “...Bu tarz filmlerin eğlence amaçlı olmasından ziyade, eğitici olması } \\
\text { gerektiğini düşündüm. Konu olarak da çağımız gerekli niteliklerini anla- } \\
\text { tıyor...” Ö10 }\end{array}$ \\
\hline
\end{tabular}

Öğretmen adayları izledikleri çizgi filmden farklı sonuçlar çıkarmışlardır. Genel olarak bu sonuçlar üç tema altında toplanmıştır. İzlenilen çizgi film sonrası çizgi filmde kişilerin kendilerini yetiştirmesi için boş zamanlarını değerlendirmeleri gerektiği, dikkat çeken konuların araştırılıp gerekirse bu düşüncelerin uygulamaya geçirebileceği katılımcıların vurguladığı konulardandır. Yine çizgi filmin sonucu olarak hedeflerin olması gerektiği, bunun da hayal gücünün sınırlarının zorlanması ile istenildikten sonra başarılabileceği ifade edilmiştir. Öğretmen adaylarından bazıları ise çizgi filmlerden bilmedikleri şeyleri öğrendiklerini, izlenen çizgi filmin kimi kavram ve konulara yer verdiği için çizgi filmi öğretici bulduklarını ifade ettikleri görülmüştür. 


\subsection{2. Çizgi film ile ilgili görüşler}

Öğretmen adaylarının çizgi filmle ile ilgili genel görüşlerini yansıtan örnek ifadelerinden bazılarına aşağıda yer verilmiştir. Öğretmen adayları genel olarak izledikleri çizgi filmi eğlenceli, dikkat çekici ve sıkılmadan izlenebilecek bir çizgi film olarak değerlendirmişlerdir.

“...Aslında gayet eğlenceli bir çizgi filmdi. Aynı zamanda yaz tatilinde çocukların boş durmayıp farklı aktivitelerde bulunmaya yöneltiyor. Çizgi filmin başlarında yaz tatili olmasına rağmen ev ödevi yapmaları ablalarının tuhafına gidiyor ve onlar da son güne bırakılmamasını söylüyorlar. Sürekli icat peşindeler ve çok bilgili çocuklar. Çizgi film olduğu için çok uçuk icatlar yapıyor olsalar da en azından boş vakit geçirmiyorlar ve kendilerini sürekli geliştiriyorlar. Olumsuz olarak bir yerde yanlış bilgi verildiğini fark ettik. Alüminyumun mıknatıslanma özelliği yoktur fakat çizgi filmde mıknatısla o tabakayı kendine çekiyor. Eğlenceli ve ilgi çekiciydi..." Ö2.

“...Çizgi filmi genel olarak sıkılmadan izledim. Öğrencilerinde sıkılmayacağını düşünüyorum. Mühendislik becerilerinin ve yaratıcılığın ön planda olduğu çizgi filmin fen bilimi açısından öğrencileri heyecanlandıracağını düşünüyorum. Genel olarak eğlenceli ve sıkılmadan izlenebilecek bir çizgi filmdi. Çocuklarda bir şeyler yaratma ve icat etme isteği uyandıracaktır. Bilime karşı merak uyandıracaktır...” Ö8. “...̇̇zlediğim çizgi film çocukların hayal gücünü desteklemesi, proje üretmeleri ve yaşayarak öğrenmeye teşvik etmesi yönüyle oldukça güzeldi. Mühendislik mesleğine yer vermesi çocukların projeyle meslek arasında bir bağ kurması için güzel bir köprü olmuş. Aynı zamanda hız treni kullanmaları fizik anlamında fikir yürütmeler için açık kapı bırakmış. Öğretmenin ders esnasında durdurup hız ile ilgili öğrencilerle sohbet etmesine imkan veriyor. Güzel ve oldukça eğlenceli buldum..." Ö5.

“...̇̇lediğim çizgi filmde hayal gücünün sınırlarını zorlayan ve yapmak istediğini zorlukları göze alarak yapan ve teknolojiyi aktif olarak kullanan çocukları gösteriyor. Aslında bu hayal gücünü geliştirici bir çizgi film fakat fazlaca gerçek dışı olması düşündürücü. Eğitici ve eğlenceli..." Ö4.

“...Çizgi film oldukça eğlenceli ve dikkat çekicidir. İçinde birazda maceracı karakterlerin bulunması çocuklarda büyük ilgiyle karşılanabilir. Illk bakışta gerçekten güzel kurgulanmış bir çizgi film olarak gözüküyor. Ancak mantık hatalarının fazla bulunduğunu düşünüyorum. Fineas ve Förb'ün yaşlarının küçük olmasına rağmen büyük işlere kalkışması oldukça ütopik bir durumdur. O kadar devasa hız treni inşa edebilecek mühendis bilgisine sahip olmaları pekte mümkün değildir. Elbette çocuklarda zoru başarma duygu- 
sunu aşılayabilir ya da büyük hedeflere çok isterseniz ulaşabilirsiniz gibi mesajlar verebilir. Ama çocuğun hayal dünyasına daha ütopik olarak hitap edecektir diye düşünüyorum. Bu yüzden biraz daha gerçekçi kurguların olduğu çizgi filmler izletilmelidir bence. Eğlenceli, renkli, maceralı ve ilk bakışta güzel buldum. Ama daha dikkatli izlediğimde ise olumsuz yönlerini gördüm. Eğitsel olarak kullanılmamalı bence..." Ö12

“...Çizgi filmde ki karakterlerin izleyecek olan öğrencilerle aynı yaş gruplarına sahip olması. Tek bir konu değil bir den fazla konu içeriyor olması. Örneğin tren raylarının mıknatısın gelip çekmesi burada mıknatısın metalleri çektiğini gösterdi ama aynı zamanda Fineas ve Förb uzaya çıkıp dünyaya doğru döndükleri sırada binmişi oldukları vagonun ön kısmında ateş belirmesi burada da atmosferdeki gazdan ve hızlarından dolayı ateş oluşmuştur. Görüldüğü üzere çizgi filmde iki farklı fen konusu vardır. Olumsuz yönleri: Yetişkin insanın yapabileceği şeyleri o yaşta ki bir çocuğun kolaylıkla yapıyor olması. Örneğin tren raylarını kendileri yapmaları ve bunun için fabrikadan gidip iş makinası almaları. Çocukların yaptıklarını annelerinden gizli yapıyor olarak gösterilmesi. Bence güzel öğrencilerime izletirim..." Ö13.

Araştırmaya katılan öğretmen adayları, karakterlerin her türlü zorluğun üstesinden gelerek hayal edilmesi oldukça güç ve hatta gerçekleşmesi mümkün olmayan şeylerin yapılmasının öğrencileri olumsuz olarak etkileyebileceğini, yaptıkları işlemleri annelerinden gizli olarak yapmalarının farklı ve yanlış bir mesaj olarak algılanabileceği riskini dile getirmişlerdir. Buna dayalı olarak da daha gerçekçi ve yaşamı yansıtan çizgi filmler izletilmesinin daha uygun olacağı görüşünü ifade etmişlerdir. İzlenilen çizgi filmde fen bilimleriyle ilgili konu ve kavramlara daha fazla yer verilmesiyle eğitimde daha verimli kullanılabileceğini gördüklerini dile getirmişlerdir. Bununla birlikte çizgi filmde bazı konu ve kavramların ise yanlış verildiğini, bu durumun da öğrencilerde kavram yanılgısı ve yanlış kavram öğrenimine neden olacağını belirtmişlerdir.

Öğretmen adaylarının, çizgi filmin öğrencilerin yaz tatili dönemini verimli geçirmede yararlı bir aktivite olarak kullanılabileceğini, karakterlerin sürekli icatlar yapmaları, projeler geliştirmeleri ile öğrencilerin yaratıcılıklarının ve mühendislik becerilerinin gelişmesine katkı sağlayacağını düşündükleri ve böylelikle de öğrencilerde bilime karşı merak ve ilginin artacağına inandıkları anlaşılmaktadır.

\section{Sonuç ve Tartışma}

Araştırmada, fen bilimleri öğretmen adaylarının eğitimde çizgi filmlerin kullanılması ve örnek çizgi filmin değerlendirmesine ilişkin görüşleri belirlenmeye çalışılmıştır. Öğretmen adayları ile yapılan görüşmeler değerlendirilip analiz edildikten sonra öğretmen adaylarının örnek ifadeleri ile desteklenerek bulgular oluşturulmuş ve bu bölümde de bulgulardan elde edilen sonuçlar ilgili alanyazınla desteklenmiştir. 
Öğretmen adayları ile yapılan görüşmeler sonrası eğitim ve çizgi filmlere ilişsin, çizgi filmlerin eğitimde kullanılabilirliği ve fen bilimleri eğitiminde çizgi film seçimi olmak üzere iki alt tema belirlenmiştir. Öğretmen adaylarının büyük çoğunluğu çizgi filmlerin eğitimde kullanılabilir olacağını düşünmektedir. Çizgi filmlerin merak uyandırıcı ve görsel olmasının öğrencilerin derse olan ilgilerini artırmak için kullanılabileceğini, bu anlamda çizgi filmlerin derse olan motivasyonu da arttıracağını ifade etmişlerdir. Demirbaş ve Yağbasan (2005) çalışmasında bilim adamlarının yaptığı çalışmaları anlatan filmlerin azlığını ve sayılarının arttırılması gerektiğini belirterek bu tür filmlerin öğrencilerin hayal gücü ve yaratıcılıklarının gelişmesinde etkili olacağını ifade etmişlerdir(s.380).

Çizgi filmlerin çocukların kişisel ve fiziksel gelişimlerine katkı sağlayacağı görüşündedirler. Benzer bir araştırma sonucu çizgi film kahramanlarının rolleri ve farklı hayat tecrübelerinin çocuğun hayal dünyasını ve zihinsel gelişimini etkilediğini göstermektedir (Oruç, Tecim, Özyürek, 2011, s.295). Kaya ve Çengel (2011) de öğretmen adaylarının, filmlerin öğrencilerin yaratıcı düşünme, eleştirel düşünme ve yorumlama becerilerini geliştirmelerine yardımcı olduğunu vurgulamışlardır (s116).

Öğretmen adayları, çizgi filmlerin fen bilimleri derslerinde kullanımı ile eğlenceli öğrenme ortamlarının oluşturulacağını, derslerin eğlenceli bir şekilde yürütüleceğini belirtmişlerdir. Aşçı (2006) da çizgi filmlerle çocukların hayal dünyasının gelişeceğini, öğretim sürecinde çocukların keyif alacağını ve öğrenme isteklerinin artacağını belirtmiştir (s.12). Çizgi filmlerin öğrencilerin hayal gücü ve yaratıcılıklarının gelişmesinde etkili olacağını ifade etmişlerdir. Ayrıca düz ve geleneksel bir anlatım yerine, fen bilimleri konuları içinde anlaşılması güç olan kavram ve olayların çizgi filmler ile görsel ve eğlenceli hale getirilerek anlatılmasının daha kalıcı öğrenme sağlayacağını vurgulamışlardır. Murat (2011), çalışmasında öğrencilere "Bunu nereden biliyorsun?" sorusunu yönelttiğinde çizgi filmde gördüklerini belirtmişlerdir (s.192). Öğrenciler çizgi filmleri sadece gülmek eğlenmek için değil aslında farkında olmadan bir eğitim öğretim aracı olarak kullanmaktadırlar. Kapucu (2014) yaptığı çalışmada görsel medyanın öğrenmeyi kolaylaştırdığı, öğretmenin anlatımını kolaylaştırdığı, dersi zevkli hale getirdiği, merakı artırdığı ve kalıcı öğrenmeyi sağladığını ifade etmiştir (s.87). Ancak öğretmen adaylarının büyük çoğunluğu çizgi filmlerin eğitimde kullanılmasında bazı sınırlılıkların olması gerektiğine vurgu yapmışlardır. Bu sınırlılıklar arasında çizgi film seçiminin evde ebeveynler, derslerde öğretmen tarafından yapılmasının gerektiğini belirtmişlerdir. Duygu ve Bekar (2017) da "Çocukların Televizyonu İzleme Durumlarının Davranış Problemlerine Etkisi" isimli araştırmasında ailesi tarafından televizyon izlemeleri kontrol edilmeyen çocukların, kontrol edilen çocuklara göre isyankâr davranışlarının daha fazla olduğu saptamış ve annelere çocuklarının izlediği televizyon programlarını izlemelerini önermişlerdir (s.191). Çizgi film seçiminin önemini vurgulayan 
bir başka çalışma sonucunda eğitsel içerikli çizgi filmleri izledikten sonra çocukların oyunlarında da daha sakin oldukları gözlenmiştir (Yaşar ve Paksoy, 2011, s.295).

Öğretmen adayları fen bilimleri derslerinde çizgi filmleri bir eğitim öğretim aracı olarak kullanabilmeleri için belli başlı özelliklere sahip olması gerektiğini belirtmişlerdir. Bu özellikler çizgi film seçiminde dikkat edilecek unsurlar teması olarak belirlenmiş ve beş alt tema "doğru bilgi kullanılması, ders içeriğine uygun, gerçeğe uygun, ilgi çekici ve eğlenceli olması" şeklinde verilmiştir. Öğretmen adayları çizgi filmleri seçerken öncelikle içeriğinin incelenmesi gerektiğini belirtmişlerdir. Yapılan bir araştırmada öğretmenlerin derste kullanmak üzere film seçiminde nelere dikkat ettikleri sorulduğunda konuya göre, dikkat çekici ve öğrenci özelliklerine, öğrenci seviyesine uygun olmasına, olumsuz örnek içermemesi ve hedeflere uygunluğuna dikkat ettiklerini belirtmiştir (Korkmaz, 2017, s.49). İçerdiği konu ve kavramların doğruluğu, eksik ya da hatalı bilgi verilip verilmediğinin önemli olduğunu vurgulamışlardır. Kullanılan çizgi filmin verilen konu ile ilişkisi ve verilecek kazanımları içerip içermediğinin yani ders içeriğine uygunluğunun kontrol edilmesine dikkat edeceklerini söylemişlerdir.

Öğretmen adayları çizgi filmlerin aşırı boyutta hayal ürünü ve gerçek dışı olmaması gerektiğinin önemli olduğunu belirtmişlerdir. Çünkü öğrencilerin izledikleri olay ve karakterleri gerçek olarak algılama durumları olasıdır. Öğretmenler ve anneler öğrencilerin genellikle şiddet içeren çizgi ve dizi filmlerdeki karakterleri taklit ettiğini, onlar gibi konuştuğunu, arkadaşları ile oyunlarında bunu gösterdiğini ve sınıfta arkadaşlarına uygulamaya çalıştıklarını belirtmişlerdir (Türkkent, 2012, s.69). Yapılan bir başka araştırmada İngiltere de 5 yaşındaki bir erkek çocuğun annesi ile alışveriş yaparken hiç tanımadığı 2 yaşındaki bir çocuğa bıçakla saldırdığı ve çizgi filmlerdeki gibi onun ölmeyeceğini düşündüğü aktarılmıştır. (Torun, 2010, s. 99; akt. Karakuş, 2015, s.252). Bir başka örnek olay 2007 de örümcek adam çizgi filminin etkisinde olan bir çocuk filmi karakterinin sadece bir hayal ürünü olduğunu, gerçekte uçamadığını ve düz duvara tırmanamadığını kabul etmeyip ısrarla ebeveynlerine, "Hayır o gerçek. Çünkü onu hep rüyalarımda görüyorum. Ben de onunla tırmanıp, uçuyorum" ifadesi çizgi filmdeki olayların farklı algılanabileceği gerçeğini göstermektedir(Esma, 2007). Bu bağlamda çizgi filmlerin seçiminin ne kadar önemli olduğu görülmektedir. Çocuk programlarının çocuklara özel olarak hazırlanmış biçim özellikleriyle anlaşılır bir şekilde sunulması gerekmektedir. Dünyayı çizgi filmler yoluyla anlamaya çalışan çocukların ilgisini çeken, onlarda merak uyandıran filmlerin kurgusu çocuk algısına uygun, anlaşılır biçimde hazırlanması önemlidir (Efe, 2014, s.35).

Öğretmen adayları seçilen çizgi filmin eğlenceli olması gerektiği görüşündedirler. Çizgi filmlerin eğlenceli ve ilgi çekici olması karışık olan fen bilimleri konularının anlaşılmasında öğrencilerin konuya olan önyargılarından kurtulmalarına neden olabilir. Öğrencilerin fen bilimleri derslerine olan kaygılarının azalması öğrenci başarısını beraberinde getirecektir. Abdüsselam (2013), yapmış olduğu çalışmada seçtikleri çizgi filmlerin çocukların 
fende anlaşılması zor olan kuvvet kavramını öğrenmede etkili olduğunu ve öğrenmede çizgi filmlerin etkili olabileceğini ifade etmiştir (s. 74). Bir başka çalışmada da animasyonlarla desteklenmiş çizgi filmlerin öğrenme sürecine dahil edilmesiyle olumlu etkilerinin olduğu görülmüştür. Öğrencilerin normal şartlarda anlamakta zorlandıkları ya da yanlış anladıkları durumların ortadan kalkacağı ve doğru anlaşılma oranının artacağı ifade edilmiştir (Dalacosta, Kamariotaki-Paparrigopoulou, Palyvos ve Spyrellis, 2009, s.747).

Öğretmen adayları fen bilimlerinde çizgi filmlerin konu seçimine ilişkin pek çok farklı konu önerisinde bulunmuşlardır. Bu önerilerden öncelikli olarak öne çıkanların "insan vücudu, kuvvet ve hareket, uzay, canlılar, güneş, doğa, deney ve fen bilimlerinde tüm konular" olduğu görülmektedir. Bununla birlikte konu önerisini isim olarak vermeyenlerinde fen bilimlerinde soyut kavramların, anlaşılması zor olan konuların ve günlük yaşam ile ilişkilendirilebilecek konuların seçilmesi şeklinde önerilerinin olduğu görülmektedir. Bayır ve Günşen (2017) yaptıkları çalışmada çizgi filmlerden bilim eğitimi açısından fırsat eğitimi olarak yeterince yararlanılmadı̆̆ sonucuna varmışlardır. Ayrıca çizgi filmlerde geçen bilimsel kavramların "teleskop, güneş enerjisi, gazlar, karışımlar, beher, tüp, asit, beş duyu organı, besinler, mikroplar, canlılar, uzay, uzay gemisi, gezegenler, dolunay, roket" ile sınırlı olduğunu belirtmişlerdir. Çizgi filmlerde geçen bilimsel kavram çeşidinin az olmasına bağlı olarak çocukların temel bazı bilimsel kavramlarla tanışmada çizgi filmlerin yetersiz kaldığını söylemişlerdir (s.755-756). Çalışmamızda da belirlenen konu ve kavramlar arasında benzerliklerin olması çizgi filmlerde yeterli düzeyde fen bilimleri konularına yer verilmediğini, bu tür eğitici çizgi filmlerin yapımı ve kullanımına ilişkin çalışmaların yapılması gerektiğini göstermektedir.

Öğretmen adayları ile eğitimde çizgi filmlere ilişkin yapılan görüşmeler sonrası ders yönetim sistemi aracılığıyla örnek bir çizgi film paylaşılmış ve verilen linkten "Fineas ve Förb-Hız Treni" isimli çizgi filmi izlemeleri istenmiştir. Değerlendirilen Fineas ve Förb isimli çizgi film içinde fen bilimleri ve konularını içeren, bilime karşı merak uyandıran, öğrencilerin hayal dünyasını ve yaratıcılığını geliştirmek için fayda sağlayabilecek bir çizgi filmdir. Çizgi film, internete bağlı birçok cihaz üzerinden yayın hizmeti sağlayan bir kuruluşun çocuklar için belirledikleri çizgi filmler arasında eğitim ve bilim kategorisi altında yer alan çizgi filmler incelenerek belirlenmiştir. Yapılan bir çalışmada da 6 yaş grubunun tercih ettikleri çizgi filmler arasında hem kızların hem de erkeklerin seçimleri dikkate alındığında çalışmamızda incelenen Fineas ve Förb çizgi filminin de yer aldığı görülmektedir(Yıldız, 2016, s.702). 
İzlenilen çizgi film sonrası öğretmen adaylarının ifadeleri çizgi filmlerin değerlendirilmesi ve çizgi film ile ilgi görüşleri olmak üzere iki alt tema altında incelenmiştir. Çizgi film değerlendirilmesi, karakterlerinin değerlendirilmesi, çizgi filmin dikkat çekici yönleri ve çizgi filmden çıkarılan sonuç olmak üzere üç tema altında değerlendirilmiştir. Öğretmen adayları karakterlerden Fineans ve Förb’ ün zeki, hayal gücü geniş ve yaratıcı özelliklerine, abla Candice'in genel olarak şikayet etmesi, olayları ispiyonlamasına, annenin hiçbir şeyi bilmemesine ve ablaya inanmamasına, doktorun bilgisini kötüye kullanmasına ve Perry'nin evcil bir hayvan olmasına vurgu yapmışlardır. Özsevgeç ve Saka, (2018), de yaptıkları çalışmada öğrenciler tarafından çizgi film seçiminin karakterlerin özellikleri dikkate alınarak yapıldığını ifade etmişlerdir. Öğrencilerin beğendikleri çizgi filmler arasında Phineas ve Ferb' ünde olduğunu beğenme nedenlerinin de karakterlerin hayal kurmaları ve yaratıcılıkları olduğunu belirtmişlerdir (s.729).

Öğretmen adayları çizgi filmin karakterlerinin, çizgi filmde yaşanan gerçek dışı olayların, çizgi filmde yer alan bilimsel kavramların dikkat çekici olduğunu belirtmişlerdir. Çocukların bilim ve bilim insanı hakkındaki görüşlerini tespit etmek için yapılan bir araştırmada çocukların zihnindeki bilim insanı figürünü, izledikleri çizgi filmlerdeki figürlerden yola çıkarak belirledikleri görülmektedir (Güler ve Akman, 2006, s.62).

Çizgi filmden çıkarılan sonuçlar kendini yetiştirme ve geliştirme, hedeflere ulaşma ve bilgi edinme temaları altında toplanmıştır. Çizgi film ile öğrencilerin yaz tatillerini verimli bir şekilde geçirecek etkinlikler yapabileceği, projeler geliştirip uygulayabilecekleri ve bu sayede kendilerini geliştirebilecek zamanlar yaratabilecek şekilde planlamalarına örnek olacağı düşünülmektedir. Çizgi filmde aşılması gereken pek çok şeyin aşılarak hedefe ulaşıldığına vurgu yapılarak istenildiğinde her şeyin başarılabileceğinin vurgusu yapılmaktadır. Ayrıca çizgi film ile fen bilimleri konuları ile pek çok bilgininde edinilebileceği sonucunun ortaya çıktığı ifade edilmektedir.

Öğretmen adaylarının izledikleri çizgi film ile ilgili genel olarak görüşleri alındı̆̆ında ise büyük çoğunluğunun örnek çizgi filmin fen bilimleri öğretiminde etkili bir şekilde kullanılabileceğini belirtmişlerdir. Çizgi filmin eğlenceli ve dikkat çekici olduğunu söylemişlerdir. Çizgi filmde yapılan icatlar ve projelerin bilime karşı ilginin artmasını sağlayacağı, öğrencilerin yaratıcıklarını ve mühendislik becerilerini geliştirmek adına aracı olacağını vurgulamışlardır. Öğretmen adayları olumlu görüşlerinin yanı sıra çizgi filmde geçen kişi ve olayların aşırı derecede hayal ürünü olmasını doğru bulmadıklarını gerçek dışı olaylara yer verilmesinin çok uygun olmayacağını belirtmişlerdir. Ayrıca doğru olmayan davranışların doğru davranışlar gibi gösterildiğini söylemişlerdir. Çizgi filmin konu içeriği açısından zenginleştirilmesinin bir eğitim öğretim materyali olarak kullanılmasına destek sağlayacağını dile getirmişlerdir. 
Çizgi filmde bazı olay ve kavramların yanlış kullanıldığını belirtmişlerdir. Örneğin alüminyum metalinin mıknatıslanma özelliğinin olduğu gibi doğru olmayan bir bilginin vurgulanmasının çocuklarda kavram yanılgısına sebep olacağı görüşündedirler. Bu yüzden eğitim öğretimde kullanılacak çizgi film seçiminin önemli olduğu düşünülmektedir. Kullanılacak çizgi filmlerin kullanıcılar tarafından dikkatli bir şekilde seçilmesi önemlidir. Bu bağlamda eğitici ve öğretici çizgi filmlerin farklı bir kategoride değerlendirilerek özenle hazırlanması gerekmektedir. Öğrencilerin çizgi filmleri izlerken belirli kazanımlar edinmeleri ile birlikte doğru konu ve kavramları etkili ve eğlenceli bir şekilde öğrenmelerine destek olunacağı düşünülmektedir.

Tüm bu sonuçların bütünsel olarak değerlendirilmesi ile özellikle de öğrencilerin zorlandıkları dersler arasında yer alan fen bilimleri dersinin farklı yöntem ve tekniklerle ele alınması gerektiği görülmektedir. Çalışmamızda öğretmen adayları çizgi filmlerin bir eğitim öğretim aracı olarak kullanılabileceğini belirtmişlerdir. Genel olarak çizgi film seçiminin önemli olduğu doğru kavram ve bilgileri içermesi gerektiği, davranış bozukluklarına eden olabilecek olayların bulunmaması gerektiği, dikkat çekici olmak adına aynı zamanda eğlenceli olması gerektiği, fen bilimlerinde yaratıcılık gibi pek çok beceriyi destekleyecek özelliklere sahip olması gerektiği vurgulanmıştır. Çizgi filmlerin içinde kısmen bazı fen kavramlarına değinildiği gözlemlenmiş, belirli konu ve kavramları içeren doğrudan eğitim öğretim materyali olarak hazırlanmış çizgi filmlerin çok az olduğu görülmüştür. Öğretim programları kazanımlarını içerecek şekilde öğretmen adaylarının çizgi film konu seçimine ilişkin pek çok öneride bulunmuşlardır. Bu bağlamda öğretmen adaylarının da belirtiği gibi fen bilimlerinde çizgi film kullanımı doğru seçim ile eğlenceli bir öğrenme ortamı sağlayarak kalıcı öğrenmeye katkı sağlayacaktır.

\section{Kaynaklar}

Abdüsselam, Z. (2013). Çizgi filmlerin Fen öğretimine etkisi: Kuvveti keşfedelim örneği. Yayınlanmamış yüksek lisans tezi, Karadeniz Teknik Üniversitesi, İlköğretim Anabilim Dalı, Trabzon. https://tez.yok.gov.tr/UlusalTezMerkezi/tezSorguSonucYeni.jsp. Tez numarası: 293194.

Aşçı, E. (2006). Televizyondaki çizgi ve animasyon karakterlerin farklı yerleşim yerlerinde yaşayan çocukların tüketici davranışlarına etkisinin incelenmesi. Yayımlanmamış Yüksek Lisans Tezi, Ankara: Ankara Üniversitesi. https://tez.yok.gov.tr/UlusalTezMerkezi/tezSorguSonucYeni.jsp. Tez numarası:180806 
Aydın, B. (2018). Türkiye'de çocuk televizyon kanallarındaki çizgi filmlerin çocukluğa etkisi üzerine bir içerik analizi. Balıkesir Üniversitesi, Sosyal Bilimler Enstitüsü, Yayınlanmamış yüksek Lisans Tezi. http://dspace.balikesir.edu.tr:8080/xmlui/handle/123456789/3408 15.11.2018 tarihinde ulaşılmıştır.

Bayır, E., \& Günşen, G. (2017). Okul öncesi dönem çocuklarının en çok izledikleri çizgi filmlerin bilimsel açılardan analizi. Trakya Üniversitesi Eğitim Fakültesi Dergisi, 7(2), 746-761.

Bekar, P., \& Arıkan, D. (2017). Çocukların televizyon izleme durumlarının davranış problemlerine etkisi. Turkiye klinikleri Journal of Nursing Sciences, 9(3), 185-192.

Cesur, S., \& Paker, O. (2007). Televizyon ve çocuk: Çocukların TV programlarına ilişkin tercihleri. Elektronik Sosyal Bilimler Dergisi, 6(19), 106-125.

Çakır, E. (2007). Yine uçacağım. http://www.hurriyet.com.tr/gundem/yine-ucacagim6591665 10.11.2018 tarihinde ulaşılmıştır.

Dalacosta, K., Kamariotaki-Paparrigopoulou, M., Palyvos, J. A., \& Spyrellis, N. (2009). Multimedia application with animated cartoons for teaching science in elementary education. Computers \& Education, 52(4), 741-748. S.747

Demirbaş, M., \& Yağbasan, R. (2005). Sosyal öğrenme teorisine dayalı öğretim etkinliklerinin, öğrencilerin bilimsel tutumlarının kalıcılığına olan etkisinin incelenmesi. Uludağ Üniversitesi Eğitim Fakültesi Dergisi, 18(2), 363-382.

Disney Channel Türkiye, 2018, 15 Eylül) Fineas \& Förb: Tam Bölüm - Hız Treni. https://www.youtube.com/watch?v=LYtqvCc3-OM

EFE, B. (2014). "Küresel Medyada Çocuk Televizyonu Yayıncılığı Türkiye'den Bir Örnek: Disney Channel", Marmara Üniversitesi Sosyal Bilimler Enstitüsü Radyo Televizyon ve Sinema Anabilim Dalı İletişim Bilimleri Bilim Dalı Yüksek Lisans Tezi, İstanbul. https://tez.yok.gov.tr/UlusalTezMerkezi/tezSorguSonucYeni.jsp (Tez Numara:367873)

Ersoy, A. F. (2016). Fenomenoloji. Eğitimde nitel araştırma desenleri [Phenomenology. Qualitative research designs in education]. (Ed: A. Saban \& A. Ersoy), (ss. 51-56). Ankara: Anı Yayıncılık. 
Asiye BERBER | Burcu ANILAN | İzel Nur ODABAŞ | Dilan ALKAN

Grafi2000, (2018a, 15 Kasım). Diş Perisi, Çürük Ali ve Mikrop Necati. https://www.youtube.com/watch?v=Z64kBHc7ziw

Grafi2000, (2018b, 15 Kasım). Temizlik, Çürük Ali ve Mikrop Necati. https://www.youtube.com/watch?v=SDx_fLmB3zw

Güler, D. (1989). Çocuk, televizyon ve çizgi film. Kurgu Anadolu Üniversitesi Iletişim Bilimleri Fakültesi Uluslararası Hakemli Iletişim Dergisi, 5(5), 163-177.

Güler, T. \& Akman, B. (2006). 6 yaş çocuklarının bilim ve bilim insanı hakkındaki görüşleri. Hacettepe Üniversitesi Eğitim Fakültesi Dergisi, 31, 55-66.

Kapucu, M. S. (2014). Fen ve teknoloji dersinde görsel medya kullanımına yönelik fen bilgisi öğretmenlerin görüşleri. Pegem Eğitim ve Öğretim Dergisi, 4(2), 75-90.

Kara, B. (2016). Çizgi filmin sosyolojik anatomisi: pepe örneği. Uluslararası Türk Kültür Coğrafyasında Sosyal Bilimler Dergisi, 1(2), 14-22.

Karakuş, N. (2015). Okul öncesi döneme hitap eden tema içerikli çizgi filmlerin değerler eğitimine katkısı yönünden değerlendirilmesi (Niloya Örneği). Değerler Eğitimi Dergisi, 13(30), 251-277.

Kaya, E., \& Çengelci, T. (2011). Öğretmen adaylarının sosyal bilgiler eğitiminde filmlerden yararlanılmasına ilişkin görüşleri. Journal of Social Studies Education Research, 2(1). 116-135

Kolojarceva, L. A., \& Artemyeva, T. V. (2017). Funny in animated films and literature: what the russian children laugh at. Journal of Fundamental and Applied Sciences, 9(7S), 1266-1276.

Korkmaz, M. (2017). Din dersi öğretmenlerinin bir öğretim materyali olarak filmleri kullanma durumları. Bilimname, 33(1), 35-66.

Koyuncu Şahin, M., Esen Çoban, A., \& Güney Karaman, N. (2018). Okul öncesi öğretmenlerinin medyanın çocukların beslenme alışkanlıkları ve bozuklukları üzerindeki etkisine yönelik bakış açıları. IIlköğretim Online, 17(1), 125-142.

Merriam, S. B. (2013). Nitel araştırma: Desen ve uygulama için bir rehber [Qualitative research: A guide for design and application] S. Turan (Trans. Ed.). Ankara: Nobel Yayıncılık. 
Murat, M., Kanadlı, S., \& Ünişen, A. (2011). Yedinci sınıf öğrencilerinin hayvanların üremesi, büyümesi ve gelişmesi konusundaki kavram yanılgıları ve olası kaynakları. Türk Fen Eğitimi Dergisi, 8(1), 179-197.

Muslu, D. (2015). Okul öncesi ve ilkokul çağı çocuklarının animasyon tekniklerine yönelik algılarının değerlendirilmesi. (Doctoral dissertation, Selçuk Üniversitesi Sosyal Bilimler Enstitüsü). http://acikerisim.selcuk.edu.tr:8080/xmlui/handle/123456789/10619 30.11.2018 tarihinde ulaşılmıştır.

Oruç, C., Tecim, E., \& Özyürek, H. (2011). Okul öncesi dönem çocuğunun kişilik gelişiminde rol modellik ve çizgi filmler. Ekev Akademi Dergisi, 15(48), 281-297.

Oruç, Ş., \& Teymuroğlu, B. (2016). Sosyal bilgiler öğretiminde çizgi film kullanımının öğrencilerin akademik başarılarına etkisi. Uluslararası Alan Eğitimi Dergisi, 2(2), 92-106.

Özdemir, A., \& Ramazan, O. (2012). Çizgi filmlerin çocukların davranışları üzerindeki etkisinin anne görüşlerine göre incelenmesi. Eğitim Bilimleri Dergisi, 35(35), 157-173.

Özen, Ö., \& Kartelli, F. (2017). Türkiye'de yayın yapan çocuk kanallarında yayınlanan çizgi filmlerdeki şiddet olgusunun analizi. Marmara Iletişim Dergisi / Marmara Journal of Communication, 27, 81-93, ISSN: 1300-4050, DOI: 10.17829/midr.20172729523

Özsevgeç, I. C., \& Saka, A. (2018). Çocukların izledikleri çizgi filmler ve bu tercihlerinin karakterleri ile ilişkisi. Uluslararası Bilimsel Araştırmalar Dergisi (IBAD), 3(2), 725-734

Patton, M.Q. (2014). Nitel araştırma ve değerlendirme yöntemleri [Qualitative research and evaluation methods]. M. Bütün \& S.B. Demir (Trans. Ed.) Ankara: Pegem Akademi

Pazarbaşı, B. (2018). Televizyonda yayınlanan ve ana teması şiddet olan çizgi filmlerin içerik analizi. Intermedia International e-Journal ISSN: 2149-3669, 5(8), 28-41.

Rai, S., Waskel, B., Sakalle, S., Dixit, S., \& Mahore, R. (2017). Effects of cartoon programs on behavioural, habitual and communicative changes in children. International Journal of Community Medicine and Public Health, 3(6), 1375-1378.

Samur, A. Ö., Demirhan, T. D., Soydan, S., \& Önkol, L. (2014). Pepee çizgi filminin ebeveyn öğretmen ve çocuk gözüyle değerlendirilmesi/assesment of pepee cartoon from perspectives of parents teachers and children. Mustafa Kemal Üniversitesi Sosyal Bilimler Enstitüsü Dergisi, 11(26), 151-166. 
Temizyürek, F., \& Acar, Ü. (2014). Çizgi filmlerdeki subliminal mesajların çocuklar üzerindeki etkisi. Cumhuriyet Uluslararası Eğitim Dergisi, 3(3), 25-39.

Türkkent, E. (2012). Okul öncesi dönem çocuklarının televizyondan etkilenmeleri konusunda anne ve öğretmen görüşleri ( Doctoral dissertation, Mehmet Akif Ersoy Üniversitesi Eğitim Bilimleri Enstitüsü). https://acikarsiv.mehmetakif.edu.tr/xmlui/handle/11672/908

Uçan, B. (2018). Türk çizgi filmlerinde kültürel kodlamalar. Journal of International Social Research, 11(55), 1134-1144.

Yaşar, M., \& Paksoy, í. (2011). Çizgi filmlerdeki saldırgan içerikli görüntülerin çocukların serbest oyunları sırasındaki saldırganlık düzeylerine etkisi. Çukurova Üniversitesi Sosyal Bilimler Enstitüsü Dergisi, 20(2), 279-298.

Yıldız, C., (2016). 3-6 Yaş çocuklarının tercih ettikleri çizgi filmlerdeki şiddet içeriklerinin analizi. Abant Izzet Baysal Üniversitesi Eğitim Fakültesi Dergisi, 16(2), 698-716. 